\title{
In-vitro Regeneration of Bambusa balcooa (Bamboo) through Nodal Segments
}

\author{
Imran Ansari, Saurabh Gupta*, Shilpi Soni and Aasif Baig \\ Shri Mukund Biotech, Jabalpur (M.P.), India \\ *Corresponding author
}

\begin{tabular}{|c|c|}
\hline & A B S T R A C T \\
\hline & \multirow{6}{*}{$\begin{array}{l}\text { Bambusa balcooa (a commercial bamboo) are the most important and fastest } \\
\text { growing species. Bambusa balcooa micro propagation protocol was established } \\
\text { for a consistent supply of quality plants. The surface sterilization of nodal explants } \\
\text { using } 0.1 \% \text { mercuric chloride followed by initiation in solid Murashige and Skoog } \\
\text { (MS) media supplemented with BA } 0.5-1.5 \mathrm{mg} / \mathrm{L} \text { as growth regulator. Shoots } \\
\text { were multiplied using MS medium with different concentrations of BA } 0.5-1.5 \\
\mathrm{mg} / \mathrm{L} \text {. In the present study we are reported that when we gradually increases BA } \\
\text { concentration from } 0.5-1.5 \mathrm{mg} / \mathrm{L} \text { the number of shoots were also increases and } \\
\text { maximum shoots were reported in BA concentration } 1.5 \mathrm{mg} / \mathrm{L} \text {. Then } 3-4 \text { shoots } \\
\text { were transferred for rooting media with NAA } 0.5-1.5 \mathrm{mg} / \mathrm{L} \text { for } 2-3 \text { weeks. During } \\
\text { the rooting we noticed that when we increases NAA concentrations from } 0.5-1.5 \\
\text { mg/L there are gradually increase in number of roots per plantlets and the } \\
\text { maximum rooting were observed in NAA concentration } 1.5 \mathrm{mg} / \mathrm{L} \text {. After root } \\
\text { development hardening were done using a mixture of coco-peat and vermi- } \\
\text { compost. }\end{array}$} \\
\hline Keywords & \\
\hline & \\
\hline Ar & \\
\hline $\begin{array}{l}\text { Accepted: } \\
29 \text { Septemb } \\
\text { Available O } \\
10 \text { October }\end{array}$ & \\
\hline & \\
\hline
\end{tabular}

\section{Introduction}

Bamboo is a perennial woody grass of family Poaceae. It is the fastest growing plant on the earth with a growth rate ranging from 30-100 $\mathrm{cm}$ per day in growing season. It can grow to a height of 36 meters with diameter of 1-30 $\mathrm{cm}$. a culm can reach its full height in matter of two to three months.

Its roots can reduce soil erosion by up to 75 percent. It is use full resource for local economies and also as structural raw material, fodder and source of fiber for paper manufacture. India is one of the leading countries in the world in bamboo production. Bamboos are also planted on private lands particularly in homesteads, field bunds and other marginal lands available. India is also very rich in bamboo diversity.

Bambusa balcooais a native India subcontinent multipurpose bamboo species height of 12-23 meters, diameter of $18-25 \mathrm{~cm}$, and grows up to $600 \mathrm{~m}$ altitude in various parts of India (Tewari, 1992). The flowering cycle of $B$. balcooa is 55-60 years, and the plant dies after flowering without seeds stings (Tewari, 1992). Vegetative propagation is difficult though culm, branch or rhizomes due to few and bulky propagules, seasonal variations, and poor rooting potential making 
this process inefficient for large scale propagation of $B$. balcooa (Pattanaik et al., 2004).

In vitro propagation method allow large scale production of the Bambusa balcooa there are few some research on use of axillary shoot portion for micro propagation of B. balcooa (Das and Pal 2005, Islam and Rahman, 2005)

This study reported on micro propagation protocol for in-vitro propagation of $B$. balcooa through axillary shoot. This is useful for land reclamation through bamboo plantation and help for rural economy and livelihood promotion.

\section{Materials and Methods}

\section{Collection of ex-plant}

The field grown healthy nodal segments of Bambusa balcooa (1.5-2.0 cm in length) were collected from 3-4 years old and disease free plant from Campus of ShriMukund biotech Lab Jabalpur. Leaf sheath tissues and dead parts of the upper internodes were removed through scalpel (Sharma et al., 2011 and Patel et al., 2015)

\section{Surface sterilization of ex-plant}

The nodal parts were thorouly washed under running tap water for 20 minutes.

They were then washed in 5\% labolene solution and $1 \%$ bavistin for 10-15 minutes and rinse with distilled water followed by $70 \%$ isopropyl alcohol.

Further treatment was done under laminar air flow. The ex-plant was treated with $0.2 \%$ mercuric chloride solution for 5-10 minutes and then thorouly washed with sterile distilled water (Jimenez et al.,. 2006 and Pandey et al., 2012)

\section{Initiation}

Initiation was carried out in Murashige and Skoog (MS) solid media with 3\% sugar, 6\% agar and different concentration of BA $(0.5$ $1.5 \mathrm{mg} / \mathrm{l})$. All cultures were stored at $25 \pm 2{ }^{\circ} \mathrm{C}$ under 16 hour's photoperiod for 2-3 weeks. This time sprouted buds elongated and developed into a multiple shoots.

\section{Shoot multiplication}

Newly sprouted axillary shoots containing 3-5 shoot propagules were sub-cultured at regular intervals of 3-4 weeks in fresh multiplication media with BA $(0.5-1.5 \mathrm{mg} / \mathrm{l})$ for induction of multiple shoots.

\section{Rooting}

Developed shoots having 8-10 shoot propagules, measuring about $3.5-6 \mathrm{~cm}$ were transferred to rooting media after completion of 4 multiplication cycles. The MS basal media with different concentrations of NAA $(0.5-1.5 \mathrm{mg} / \mathrm{l})$ were used for rooting. All cultures were transferred in plant tissue culture chamber for 2-3 weeks.

\section{Hardening}

In-vitro plantlets were removed from culture bottles, washed thoroughly under running water to remove traces of medium from roots. Plantlets were transferred to hardening trays consist of 3:1 ratio of coco peat and vermicompost. The plants were grown under greenhouse conditions maintained at $25-30{ }^{\circ} \mathrm{C}$ temperature and relative humidity of $75 \%$ for 3-4 weeks (Beena et al., 2015).

\section{Results and Discussion}

MS media (solid media) were used for the development of nodal ex-plant (B. balcooa) with different concentration of plant growth 
regulators (BA 0.5-1.5 and NAA 0.5-1.5). The treated nodal cultures inoculated in the solid MS media.

After 2-3 weeks highest shoot development is found in MS media with BA concentration $1.5 \mathrm{mg} / \mathrm{L}$ i.e. $8.2 \pm 2.4$ shoots per explant and

\section{A. Shoot initiation from axillary buds}

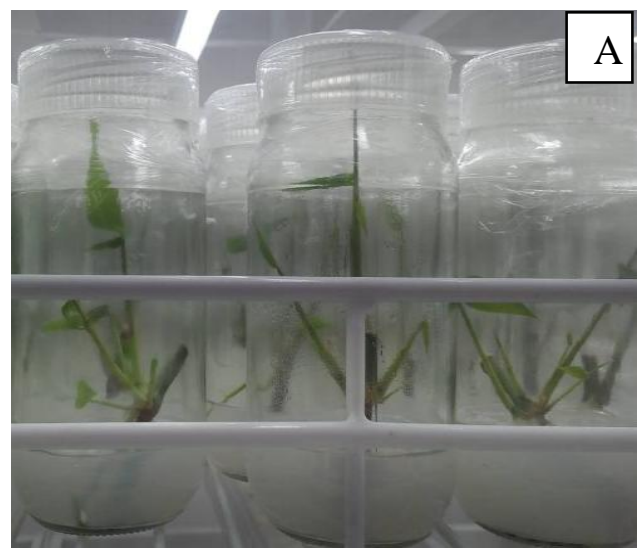

C. Effect of NAA $(1.5 \mathrm{mg} / \mathrm{L})$ in rooting

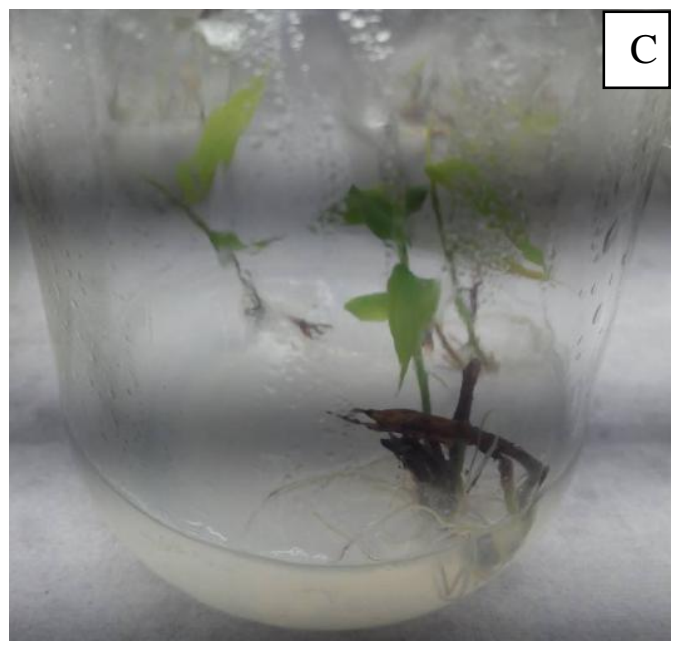

highest shoot length $3.8 \pm 0.4$ were recorded. Similar observation were also made by Sharma et al., 2011 and Patel et al., 2015.

Mature buds were then transferred in multiplication media for 2-3 weeks at controlled conditions.

\section{B. Shoot multiplication [Effect of BA (1.5 mg/L)]}

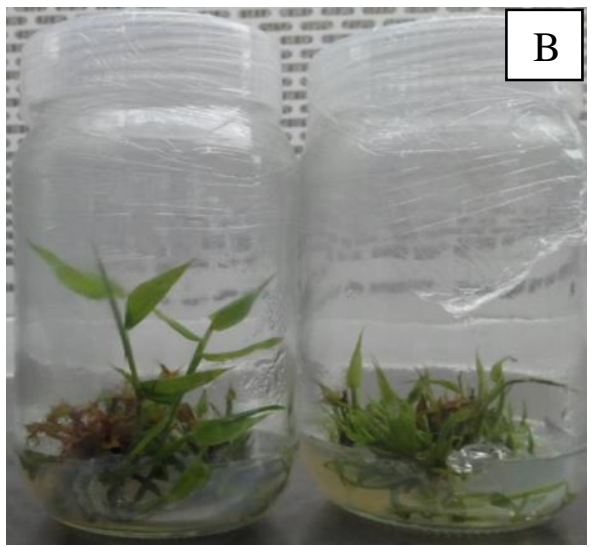

D. Plantation at Green House

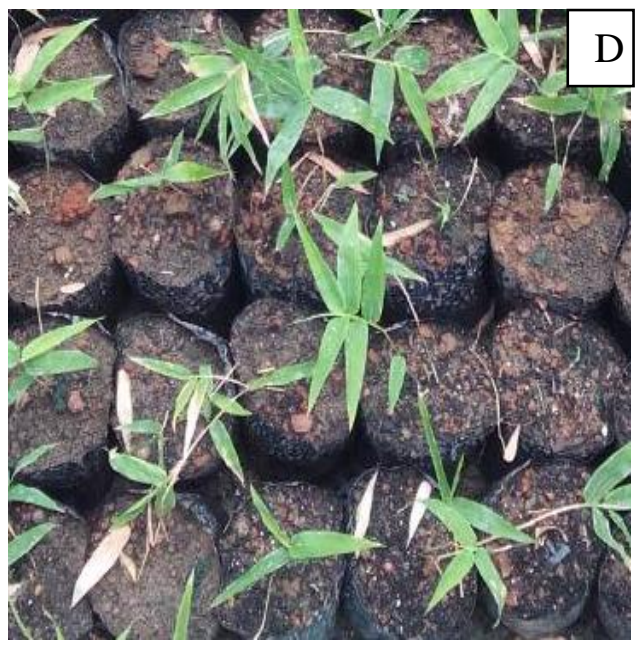

Table.1 Effect of BA in MS media on Shooting

\begin{tabular}{|l|c|c|c|c|}
\hline S. No. & Media & Concentration $(\mathbf{m g} / \mathbf{l})$ & Number of Shoot & Shoot length \\
\hline 1 & MS + BA & 0.5 & $3.8 \pm 0.2$ & $1.2 \pm 0.1$ \\
\hline 2 & MS + BA & 1.0 & $5.0 \pm 1.2$ & $2.6 \pm 1.3$ \\
\hline 3 & MS + BA & 1.5 & $8.2 \pm 2.4$ & $3.8 \pm 0.4$ \\
\hline
\end{tabular}


Table.2 Effect of NAA in MS media on Rooting

\begin{tabular}{|l|l|c|c|c|}
\hline S. No. & Media & Concentration $(\mathbf{m g} / \mathbf{l})$ & Number of Shoot & Shoot length \\
\hline 1 & MS + BA & 0.5 & $1 \pm 1$ & $0.1 \pm 0.2$ \\
\hline 2 & MS + BA & 1.0 & $3 \pm 1$ & $1.5 \pm 0.5$ \\
\hline 3 & MS + BA & 1.5 & $4 \pm 1$ & $2.3 \pm 0.3$ \\
\hline
\end{tabular}

Best shoot multiplication was found in media containing BA $1.5 \mathrm{mg} / \mathrm{l}$. The newly developed shoots were recoreded in 5-8 numbers whose shoot length were $3.8 \pm 0.4$ observed. Best period for recycling of multiplication shoots was recorded i.e. 18 days old culture. Same result was observed by Mudai and Borthaker 2009. For root induction developed shoot bunch (3-4 shoots) were placed in the media containing different concentration of NAA $(0.5-1.5 \mathrm{mg} / \mathrm{l})$. Best result was recorded $(4 \pm 1$ roots) in media containing $1.5 \mathrm{mg} / \mathrm{l} \mathrm{NAA}$ whose length was $2-3 \mathrm{~cm}$ recorded after 2-3 weeks. Same results were observed by Arya et al., 2002 and Pratibha and Sharma, 2011. The developed rooted plants were washed under running tap water and plants were transferred to root trainer with mixture contain coco-peat and vermin-compost into 3:1 ratio then add to some water and kept in close condition and maintaining the humidity at green house for 20-30 days. The 90\% survival rate was recorded from developed rooted B. balcooa.

\section{Acknowledgement}

The authors acknowledge to Director and research team of Shri Mukund Biotech, Jabalpur for providing research facility.

\section{References}

Arya, I.D., Rana, P.K., Satsangi R., Muzaffar F.S., Sharma, S., Arya S. Rapid and mass multiplication of bamboos through tissue culture techniques. In: Nandi SK, Palni LM, Kumar, G.B., editors. Role of Plant Tissue Culture in Biodiversity
Conservation and Economic Development. Nainital: Gyanodaya Prakashan; 2002. p. 29-30.

Beena, P., Bharat G, Nisha P, Vipul B, (2015). One step pre-hardening micro propagation of Bambusa balcooa Roxb. Journal of phytology 2015, 7: 1-9.

Das, M., Pal A. Clonal propagation and production of genetically uniform regenerants from axillary meristems of adult bamboo. $J$ Plant Biochem Biotechnol 2005a; 14:185-8.

Islam, S.A., Rahman MM. Micro-cloning in commercially important six bamboo species for mass propagation and at large scale cultivation. Plant Tissue Cult Biotech 2005; 15:103-11.

Jimenez, V.M., Tavares E, Guevara E, Montiel M (2006). In vitro propagation of the neotroical gaint bamnoo guaduaan gustifoliakunth, through axillary shoot prolifertion. Plant cell tissue organ cult.89: 389-395

Mudoi, K.D., Borthakur M. In vitro micro propagation of Bambusa balcooa Roxb. Through nodal explants from fieldgrown culms and scope for up scaling. CurrSci 2009; 96:962-6.

Pandey, N.B., and Singh, B.N., 2012. Micropropagation of Dendrocalamus Strictus Nees from mature nodal explants. Journal of Applied Natural Science 4: 5-9.

Patel, B., Gami B, Patel N, Baria V (2015) One step pre-hardening micro propagation of Bambusa balcooa Roxb. Journal of Phytology 7: 1-9

Pattanaik, S., Das P, Borah E, Kaur H, Borah K. Vegetative multiplication of 
Bambusa balcooa Roxb. Using branch cuttings. J Bamboo Rattan 2004; 3:36574.

Pratibha, S., Sarma, K.P. In vitro propagation of Bambusa balcooa for a better environment. International Conference on Advances in Biotechnology and Pharmaceutical Sciences (ICABPS' 2011) Bangkok. 2011. p. 248-52.

Tewari, D.N., A Monograph on Bamboo. Dehradun, India: International Book Distributors; 1992. p. 31-2.

\section{How to cite this article:}

Imran Ansari, Saurabh Gupta, Shilpi Soni and Aasif Baig. 2017. In-vitro Regeneration of Bambusa balcooa (Bamboo) through Nodal Segments. Int.J.Curr.Microbiol.App.Sci. 6(10): 4901-4905. doi: https://doi.org/10.20546/ijcmas.2017.610.460 